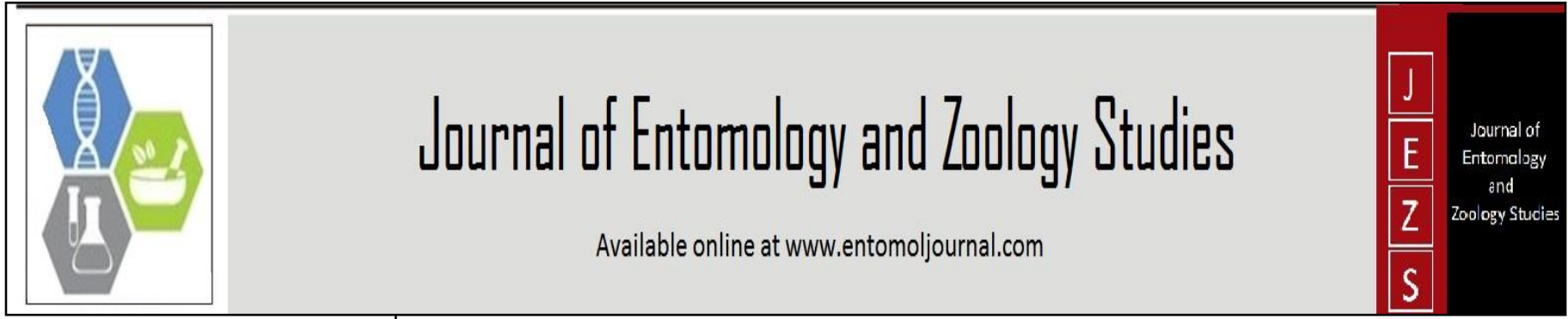

E-ISSN: 2320-7078

P-ISSN: 2349-6800

www.entomoljournal.com JEZS 2021; 9(6): 193-196 (C) $2021 \mathrm{JEZS}$

Received: 19-09-2021

Accepted: 21-10-2021

\section{Band SS}

Ph.D. Scholar, Department of Agriculture Entomology, Post Graduate Institute, MPKV,

Rahuri, Maharashtra, India

\section{Kabre GB}

Professor of Entomology, Agriculture Entomology Section, College of Agriculture, Dhule, Maharashtra, India

\section{Kulkarni SR}

Professor of Entomology, Department of Agriculture Entomology, Post Graduate Institute, MPKV, Rahuri,

Maharashtra, India

Saindane YS

Assistant Residue Analyst AINP on Residue, Post Graduate Institute, MPKV, Rahuri,

Maharashtra, India

\section{Navale AM}

Professor of Plant Pathology and Microbiology, Department of Plant Pathology and Microbiology, Post Graduate Institute, MPKV, Rahuri, Maharashtra, India

\section{Corresponding Author:} Band SS

Ph.D. Scholar, Department of Agriculture Entomology, Post Graduate Institute, MPKV, Rahuri, Maharashtra, India

\section{Effect of chemical pesticides on vegetative growth of M. anisopliae in compatibility studies}

\author{
Band SS, Kabre GB, Kulkarni SR, Saindane YS and Navale AM
}

DOI: https://doi.org/10.22271/j.ento.2021.v9.i6c.8898

\section{Abstract}

The results on compatibility of different chemical pesticides with $M$. anisopliae clearly indicate that the highest mycelial growth $(75.17 \mathrm{~mm})$ was observed in flonicamid $50 \%$ WG followed by imidacloprid $17.8 \%$ SL $(70.50 \mathrm{~mm})$. The minimum (16.48 per cent) growth inhibition of $M$. anisopliae was observed in pesticidal treatment with flonicamid $50 \%$ WG which indicates its better compatibility with $M$. anisopliae. Among chemical pesticides tested for their compatibility, the minimum per cent growth inhibition was observed in flonicamid 50\% WG (16.48 per cent) followed by imidacloprid 17.8 SL (21.67 per cent), deltamethrin $2.5 \%$ EC (26.30 per cent) and chlorantraniliprole $18.5 \%$ SC (27.78 per cent) indicating better compatibility with $M$. anisopliae than dimethoate $30 \%$ EC (69.07 per cent), clothanidin $25 \%$ WG (54.81 per cent) and difenthiuron 50\% WP (51.30 per cent) in which more than 50 per cent growth inhibition was observed. Among fungicides, all the three fungicides propiconazole $25 \%$ EC (94.44 per cent), difenoconazole 25\% EC (77.22 per cent) and copper oxychloride 50\% WP (56.85 per cent) indicating that they are not compatible with M. anisopliae.

Keywords: compatibility, mycelial growth, pesticides, growth inhibition, fungicide

\section{Introduction}

In order to conserve the ecofriendly biological microorganisms, biological control agents in nature, particularly within agricultural and horticultural ecosystems, must be protected from a wide range of harmful pesticides. As a result, determining their compatibility and interaction with pesticides, which is a key component of IPM programmes, is critical. In vitro studies have shown that various pesticides have selective effect on entomofungal infections, according to several researchers (Alves, 1986; Silva et al., 1993) ${ }^{[2,13]}$. To increase insect mortality, a compatible admixture of insecticides at sub-lethal concentrations and entomopathogenic fungus can operate synergistically. This is especially advantageous since it lowers the insecticide application dose, reduces environmental contamination and lowers the risk of resistance. To provide safe and effective control of insect pests, several compatible insecticides with entomopathogenic fungi and other biocontrol agents are utilized in various combinations (Asi et al., 2010; Bitsadze et al., 2013) ${ }^{[3,5]}$.

Insecticides have a negative impact on non-target predatory organisms in nature, including EPFs like B. bassiana and M. anisopliae, which are entomopathogenic fungi. However, there are interactions between insecticides and entomopathogens. Insecticides at low doses combined with an entomopathogenic fungus can work together to increase insect pest mortality. This combination is especially beneficial since it reduces the amount of insecticide used, reduces environmental contamination and reduces pest resistance (Abidin et al., 2017) [1].

\section{Materials and Method}

The investigation on compatibility of Metarhizium anisopliae with botanical, biorational and chemical pesticides were carried out in Biocontrol laboratory, Department of Agriculture Entomology, Post Graduate Institute, MPKV, Rahuri, during 2020-2021.

\section{Poison food technique}

Standard poison food technique was followed to assay the effect of botanical, biorational and chemical pesticides on $M$. anisopliae. 


\section{Quantity of pesticide required}

The amount of toxicant (i.e. actual ingredient) in required quantity of PDA was calculated with the help of following formula,

Percent of solution desired $\times$ Quantity of solution required Amount of pesticide required $=$

Strength of the formulation available

The insecticide doses were calculated for field application rate based on 500 litres/ha or with high volume sprayers. The pesticides were evaluated by poisoned food technique. Requisite quantity of chemical pesticides (Table 1) were added to the PDA medium in flask before solidification (medium temperature $46-48^{\circ} \mathrm{C}$ ) to get desired concentration and mixed thoroughly. Then poured equally into the three petriplates and kept in laminar air flow. The medium was aseptically allowed to solidify under laminar air flow cabinet. After complete cooling of the PDA medium in petriplates the culture of $M$. anisopliae were inoculated under aseptic condition. Mycelial mat was cut with sterile cork borer $(5 \mathrm{~mm}$ diameter) from 10 days old culture of $M$. anisopliae and placed aseptically in the centre of petriplates containing the poisoned media. Suitable check without poison was kept for comparison under same condition. Fungal colony diameter was measured at $3^{\text {rd }}, 5^{\text {th }}$ and $7^{\text {th }}$ days after inoculation and compared with standard check to measure the degree of toxicity of different pesticides used in study. Inhibition of colony growth over untreated check was worked out for respective pesticides.

\section{Vegetative growth of $M$. anisopliae}

Radial mycelial growth of the fungus was measured after $3^{\text {rd }}$, $5^{\text {th }}$ and $7^{\text {th }}$ days after inoculation and compared with untreated control. The per cent reduction in radial growth was calculated by using formula, $\mathrm{R}=\mathrm{C}-\mathrm{T} / \mathrm{C} \times 100$

Where, $\mathrm{R}$ - Per cent reduction of radial growth

C - Radial growth of fungi grown on untreated medium

$\mathrm{T}$ - Radial growth of fungi grown on pesticide treated medium

The experiments were carried out under laboratory condition in completely randomized design during the year 2020-21 with 3 replications \& 11 treatments of chemical pesticides. The data so obtained was analyses by standard statistical procedures.

Table 1: Details of the chemical pesticides used to study compatibility of $M$. anisopliae

\begin{tabular}{|c|c|c|c|c|}
\hline \multirow{2}{*}{ Sr. No } & \multirow{2}{*}{ Active Ingredient } & \multirow{2}{*}{ Dose/liter } & \multicolumn{2}{|c|}{ Dose $(\mathrm{ml} / \mathrm{g}) / \mathrm{ha}$} \\
\hline & & & a.i.(g) & $\mathrm{g} / \mathrm{ml}$ \\
\hline $\mathrm{T}_{1}$ & Dimethoate $30 \%$ EC & $2.0 \mathrm{ml} / 1$ & 300 & 1000 \\
\hline $\mathrm{T}_{2}$ & Imidacloprid $17.8 \%$ SL & $0.25 \mathrm{ml} / 1$ & 22.25 & 125 \\
\hline $\mathrm{T}_{3}$ & Deltamethrin $2.5 \% \mathrm{SC}$ & $1.5 \mathrm{ml} / 1$ & 18.75 & 750 \\
\hline $\mathrm{T}_{4}$ & Difenthiuron $50 \%$ WP & $1.2 \mathrm{~g} / \mathrm{l}$ & 300 & 600 \\
\hline $\mathrm{T}_{5}$ & Flonicamid 50\% WG & $0.2 \mathrm{~g} / \mathrm{l}$ & 50 & 100 \\
\hline $\mathrm{T}_{6}$ & Clothanidin 25\% WDG & $0.1 \mathrm{~g} / 1$ & 12.50 & 50 \\
\hline $\mathrm{T}_{7}$ & Chlorantraniliprole $18.5 \% \mathrm{SC}$ & $0.3 \mathrm{ml} / 1$ & 27.75 & 150 \\
\hline $\mathrm{T}_{8}$ & Copper Oxychloride 50\% WP & $2.5 \mathrm{~g} / 1$ & 625 & 1250 \\
\hline $\mathrm{T}_{9}$ & Propiconazole $25 \%$ EC & $1.5 \mathrm{ml} / \mathrm{l}$ & 187.5 & 750 \\
\hline $\mathrm{T}_{10}$ & Difenoconazole $25 \%$ EC & $1.0 \mathrm{ml} / \mathrm{l}$ & 125 & 500 \\
\hline $\mathrm{T}_{11}$ & Untreated check & - & - & - \\
\hline
\end{tabular}

\section{Result and Discussion}

At $3^{\text {rd }}$ day after inoculation, the data on the impact of chemical pesticides on mean mycelial growth and percent growth inhibition of $M$. anisopliae revealed that the untreated control had the maximum $(52.00 \mathrm{~mm})$ mycelial growth and was considerably superior to the other treatments. Among the various pesticides tested for their compatibility with $M$. anisopliae the highest $(33.33 \mathrm{~mm})$ mycelial growth was observed in imidacloprid $17.8 \%$ SL and was significantly superior over rest of the pesticides. The next superior treatment for their compatibility was flonicamid 50\% WG with mean mycelial growth $30.83 \mathrm{~mm}$.

Table 2: Effect of various pesticides on vegetative growth and growth inhibition of M. anisopliae

\begin{tabular}{|c|c|c|c|c|c|c|c|c|}
\hline \multirow{3}{*}{ Treatment } & \multirow{2}{*}{\multicolumn{2}{|c|}{ Dose }} & \multicolumn{2}{|c|}{3 DAI } & \multicolumn{2}{|c|}{5 DAI } & \multicolumn{2}{|c|}{7 DAI } \\
\hline & & & \multirow{2}{*}{$\begin{array}{c}\text { Mean } \\
\text { mycelial } \\
\text { growth } \\
(\mathbf{m m})\end{array}$} & \multirow{2}{*}{$\begin{array}{c}\text { Mean } \\
\text { growth } \\
\text { inhibition } \\
(\%)\end{array}$} & \multirow{2}{*}{$\begin{array}{c}\text { Mean } \\
\text { mycelial } \\
\text { growth } \\
(\mathbf{m m})\end{array}$} & \multirow{2}{*}{$\begin{array}{c}\text { Mean } \\
\text { growth } \\
\text { inhibition } \\
(\%)\end{array}$} & \multirow{2}{*}{$\begin{array}{c}\text { Mean } \\
\text { mycelial } \\
\text { growth } \\
(\mathbf{m m})\end{array}$} & \multirow{2}{*}{$\begin{array}{c}\text { Mean } \\
\text { growth } \\
\text { inhibition } \\
(\%)\end{array}$} \\
\hline & $\begin{array}{c}(\mathrm{gm} / \mathrm{ml}) / \\
\text { ha }\end{array}$ & $\begin{array}{c}(\mathrm{gm} / \mathrm{ml}) / \\
\text { Lit. }\end{array}$ & & & & & & \\
\hline Dimethoate $30 \%$ EC & 1000 & 2.0 & $\begin{array}{c}20.00 \\
(4.53)^{*}\end{array}$ & $\begin{array}{c}61.54 \\
(51.67)^{* *}\end{array}$ & $\begin{array}{l}23.67 \\
(4.92)^{*}\end{array}$ & $\begin{array}{c}68.24 \\
(55.69) * *\end{array}$ & $\begin{array}{c}27.83 \\
(5.32)^{*}\end{array}$ & $\begin{array}{c}69.07 \\
(56.21)^{* *}\end{array}$ \\
\hline $\begin{array}{c}\text { Imidacloprid } 17.8 \% \\
\text { SL }\end{array}$ & 125 & 0.25 & $\begin{array}{l}33.33 \\
(5.82) \\
\end{array}$ & $\begin{array}{c}35.83 \\
(36.74) \\
\end{array}$ & $\begin{array}{l}41.50 \\
(6.48) \\
\end{array}$ & $\begin{array}{c}44.26 \\
(41.70) \\
\end{array}$ & $\begin{array}{l}70.50 \\
(8.42) \\
\end{array}$ & $\begin{array}{c}21.67 \\
(27.70) \\
\end{array}$ \\
\hline $\begin{array}{c}\text { Deltamethrin } 2.5 \% \\
\text { SC }\end{array}$ & 750 & 1.5 & $\begin{array}{l}23.67 \\
(4.92) \\
\end{array}$ & $\begin{array}{c}54.49 \\
(47.58) \\
\end{array}$ & $\begin{array}{l}34.67 \\
(5.93) \\
\end{array}$ & $\begin{array}{c}53.47 \\
(46.99) \\
\end{array}$ & $\begin{array}{l}66.33 \\
(8.17) \\
\end{array}$ & $\begin{array}{c}26.30 \\
(30.82) \\
\end{array}$ \\
\hline $\begin{array}{c}\text { Difenthiuron } 50 \% \\
\text { WP }\end{array}$ & 600 & 1.2 & $\begin{array}{l}25.83 \\
(5.13) \\
\end{array}$ & $\begin{array}{c}50.27 \\
(45.16) \\
\end{array}$ & $\begin{array}{l}32.17 \\
(5.71)\end{array}$ & $\begin{array}{c}56.77 \\
(48.89)\end{array}$ & $\begin{array}{l}43.83 \\
(6.66) \\
\end{array}$ & $\begin{array}{c}51.30 \\
(45.74) \\
\end{array}$ \\
\hline $\begin{array}{c}\text { Flonicamid 50\% } \\
\text { WG }\end{array}$ & 100 & 0.2 & $\begin{array}{l}30.83 \\
(5.60) \\
\end{array}$ & $\begin{array}{c}40.67 \\
(39.62) \\
\end{array}$ & $\begin{array}{l}42.33 \\
(6.54) \\
\end{array}$ & $\begin{array}{c}43.14 \\
(41.05) \\
\end{array}$ & $\begin{array}{l}75.17 \\
(8.70) \\
\end{array}$ & $\begin{array}{c}16.48 \\
(23.94) \\
\end{array}$ \\
\hline $\begin{array}{c}\text { Clothanidin } 25 \% \\
\text { WDG }\end{array}$ & 50 & 0.1 & $\begin{array}{l}17.17 \\
(4.20)\end{array}$ & $\begin{array}{c}67.02 \\
(54.95)\end{array}$ & $\begin{array}{l}30.33 \\
(5.55) \\
\end{array}$ & $\begin{array}{l}59.30 \\
(50.36) \\
\end{array}$ & $\begin{array}{l}40.67 \\
(6.42) \\
\end{array}$ & $\begin{array}{c}54.81 \\
(47.76) \\
\end{array}$ \\
\hline $\begin{array}{c}\text { Chlorantraniliprole } \\
18.5 \% \mathrm{SC}\end{array}$ & 150 & 0.3 & $\begin{array}{l}26.83 \\
(5.23)\end{array}$ & $\begin{array}{c}48.39 \\
(44.08)\end{array}$ & $\begin{array}{l}39.50 \\
(6.32)\end{array}$ & $\begin{array}{c}46.95 \\
(43.25)\end{array}$ & $\begin{array}{l}65.00 \\
(8.09)\end{array}$ & $\begin{array}{c}27.78 \\
(31.78)\end{array}$ \\
\hline
\end{tabular}




\begin{tabular}{|c|c|c|c|c|c|c|c|c|}
\hline $\begin{array}{c}\text { Copper Oxychloride } \\
50 \% \text { WP } \\
\end{array}$ & 1250 & 2.5 & $\begin{array}{l}16.00 \\
(4.06) \\
\end{array}$ & $\begin{array}{c}69.25 \\
(56.33) \\
\end{array}$ & $\begin{array}{l}31.67 \\
(5.67) \\
\end{array}$ & $\begin{array}{c}57.42 \\
(49.28) \\
\end{array}$ & $\begin{array}{l}38.83 \\
(6.27) \\
\end{array}$ & $\begin{array}{c}56.85 \\
(48.94) \\
\end{array}$ \\
\hline $\begin{array}{c}\text { Propiconazole } 25 \% \\
\text { EC } \\
\end{array}$ & 750 & 1.5 & $\begin{array}{c}5.00 \\
(2.35) \\
\end{array}$ & $\begin{array}{c}90.38 \\
(71.93)\end{array}$ & $\begin{array}{c}5.00 \\
(2.35) \\
\end{array}$ & $\begin{array}{c}93.29 \\
(74.98)\end{array}$ & $\begin{array}{c}5.00 \\
(2.35) \\
\end{array}$ & $\begin{array}{c}94.44 \\
(76.37)\end{array}$ \\
\hline $\begin{array}{c}\text { Difenoconazole } \\
25 \% \mathrm{EC}\end{array}$ & 500 & 1.0 & $\begin{array}{c}9.17 \\
(3.11)\end{array}$ & $\begin{array}{c}82.39 \\
(65.19) \\
\end{array}$ & $\begin{array}{l}15.83 \\
(4.04)\end{array}$ & $\begin{array}{c}78.74 \\
(62.54) \\
\end{array}$ & $\begin{array}{l}20.50 \\
(4.58)\end{array}$ & $\begin{array}{c}77.22 \\
(61.50) \\
\end{array}$ \\
\hline Untreated check & -- & - & $\begin{array}{l}52.00 \\
(7.25)\end{array}$ & $\begin{array}{c}0.00 \\
(0.00)\end{array}$ & $\begin{array}{l}74.50 \\
(8.66)\end{array}$ & $\begin{array}{c}0.00 \\
(0.00)\end{array}$ & $\begin{array}{l}90.00 \\
(9.51)\end{array}$ & $\begin{array}{c}0.00 \\
(0.00)\end{array}$ \\
\hline $\mathrm{SE} \pm$ & & & 0.06 & 0.65 & 0.07 & 0.73 & 0.07 & 0.77 \\
\hline $\mathrm{CD}$ at $5 \%$ & & & 0.17 & 1.92 & 0.20 & 2.16 & 0.21 & 2.28 \\
\hline
\end{tabular}

*Figures in parenthesis are $\sqrt{\mathrm{x}}+0.5$ transformed values. **Figures in parenthesis are arc sin transformed values

The fungicide propiconazole $25 \%$ EC was not found compatible with $M$. anisopliae, as no mycelial growth was observed at $3^{\text {rd }}$ day after inoculation and it shows maximum $90.38 \%$ growth inhibition of $M$. anisopliae. The minimum $(35.83 \%)$ growth inhibition of $M$. anisopliae was observed in pesticide treatment with imidacloprid $17.8 \%$ SL and was significantly superior over rest of the pesticides which indicates its better compatibility with $M$. anisopliae. The next superior treatment in per cent growth inhibition was flonicamid 50\% WG (40.67\%) (Table 2).

The Data on effect of pesticides on mycelial growth and growth inhibition of $M$. anisopliae at $5^{\text {th }}$ day after inoculation revealed that the highest $(74.50 \mathrm{~mm})$ mycelial growth was observed in untreated check and was significantly superior over the rest of the pesticidal treatments. Among the various pesticides tested for their compatibility with M. anisopliae the highest $(42.33 \mathrm{~mm})$ mycelial growth was observed in flonicamid $50 \% \mathrm{WG}$ and was at par with imidacloprid $17.8 \%$ SL $(41.50 \mathrm{~mm})$. The fungicide propiconazole $25 \% \mathrm{EC}$ was not found compatible with $M$. anisopliae, as no mycelial growth was observed at $5^{\text {th }}$ day after inoculation and it shows maximum $93.29 \%$ growth inhibition of $M$. anisopliae. The minimum (43.14\%) growth inhibition of $M$. anisopliae was observed in pesticide treatment with flonicamid $50 \% \mathrm{WG}$ and was at par with imidacloprid $17.8 \%$ SL (44.26\%) and chlorantraniliprole $18.5 \mathrm{SC}(46.95 \%)$ which indicates their better compatibility with $M$. anisopliae (Table 2).

The Data on effect of pesticides on mycelial growth and growth inhibition of $M$. anisopliae at $7^{\text {th }}$ day after inoculation revealed that the highest $(90.00 \mathrm{~mm})$ mean mycelial growth was observed in untreated check and was significantly superior over the rest of the pesticidal treatments. Among the various pesticides tested for their compatibility with $M$. anisopliae the highest $(75.17 \mathrm{~mm})$ mycelial growth was observed in flonicamid $50 \% \mathrm{WG}$ followed by imidacloprid $17.8 \% \mathrm{SL}(70.50 \mathrm{~mm})$. The fungicide propiconazole $25 \% \mathrm{EC}$ was not found compatible with $M$. anisopliae as no mycelial growth was observed even at $7^{\text {th }}$ day after inoculation and it shows maximum $94.44 \%$ growth inhibition of $M$. anisopliae. The minimum (16.48\%) growth inhibition of $M$. anisopliae was observed in insecticidal treatment with flonicamid $50 \%$ WG and was significantly superior over rest of the pesticides which indicates its better compatibility with $M$. anisopliae. The next superior treatment in per cent growth inhibition was imidacloprid $17.8 \%$ SL $(21.67 \%)$. The results on compatibility of chemical pesticides with $M$. anisopliae clearly indicates that the pesticides having better compatibility with $M$. anisopliae as having maximum mean mycelial growth in descending order are flonicamid 50\% WG $>$ imidacloprid $17.8 \% \mathrm{SL}>$ deltamethrin $2.5 \% \mathrm{SC}>$ chlorantraniliprole $18.5 \% \mathrm{SC}>$ difenthiuron $50 \% \mathrm{WP}>$ clothanidin 25\% WDG > copper oxychloride 50\% WP > dimethoate $30 \% \mathrm{EC}>$ difenoconazole $25 \% \mathrm{EC}>$ propiconazole $25 \% \mathrm{EC}$ at $7^{\text {th }}$ day after inoculation (Table 2). The results clearly indicates that among chemical pesticides the minimum per cent growth inhibition was observed in flonicamid $50 \%$ WG (16.48\%) followed by imidacloprid 17.8 SL (21.67\%), deltamethrin $2.5 \%$ EC (26.30\%) and chlorantraniliprole $18.5 \%$ SC $(27.78 \%)$ indicating better compatibility with $M$. anisopliae then dimethoate $30 \%$ EC $(69.07 \%)$, clothanidin $25 \%$ WG $(54.81 \%)$ and difenthiuron $50 \%$ WP $(51.30 \%)$ in which more than $50 \%$ growth inhibition was observed. Among fungicides, all the three fungicides propiconazole $25 \%$ EC (94.44\%), difenoconazole $25 \%$ EC (77.22\%) and copper oxychloride 50\% WP (56.85\%) indicating that they are not compatible with $M$. anisopliae (Table 2)

The present finding on compatibility of $M$. anisopliae with chemical pesticides are in corroboration with Sain et al. (2019) ${ }^{[12]}$ who studied compatibility with the EPF in comparison to other chemical pesticides such as imidacloprid, fipronil, profenophos and triazophos, M. anisopliae with insecticides such as spiromesifen, difenthiuron, buprofezin, pyriproxyfen, and flonicamid were more compatible with EPFs at half doses. The present finding of the vegetative growth rate of $M$. anisopliae are in agreement with Khan et al. (2012) ${ }^{[7]}$ who reported that imidacloprid $(0.005 \%)$ were highly safe and most compatible to these $M$. anisopliae. In present findings also imidacloprid had shown better compatibility with M. anisopliae. Niassy et al. (2012) who studied the compatibility of the Metarhizium anisopliae (Metschnikoff) Sorokin isolate ICIPE 69, with insecticides, viz., thiamethoxam and imidacloprid. Results revealed that the insecticide imidacloprid was highly compatible with Metarhizium anisopliae are in confirmation with present findings. Filho et al. (2001) ${ }^{[5]}$ who studied compatibility of entomopathogenic fungus, $M$. anisopliae with thiamethoxam and imidacloprid. Statistical analysis showed that the reproductive and vegetative growth of $M$. anisopliae was not affected by thiamethoxam and imidacloprid. In present findings also imidacloprid had shown better compatibility with Metarhizium anisopliae. In conformation with the findings of Joshi et al. (2018) ${ }^{[6]}$ who studied that in-vitro toxicity of four fungicides, viz., mancozeb $75 \%$ WP, carbendazim $50 \% \quad \mathrm{WP}$, propiconazole $25 \% \quad \mathrm{EC}$ and hexaconazole $5 \% \mathrm{EC}$ at different concentration for their effect on growth, inhibitory or synergistic effects and spore germination of Beauveria bassiana and Metarhizium anisopliae by growing them on insecticides and fungicides treated media. Among all fungicides tested only mancozeb $75 \%$ WP proved safe up to some extent at lower concentrations $(0.5$ and $0.25 \%)$ to test fungi with average amount of spore germination, whereas carbendazim 50\% WP, hexaconazole 5\% EC and propiconazole $25 \%$ EC were completely inhibitory in its action at all the concentrations. In present findings all the three fungicides, viz., propiconazole 
$25 \%$ EC, difenoconazole 25\% EC and copper oxychloride $50 \%$ WP completely inhibiting the mycelial growth of $M$. anisopliae revealing that they are not compatible with $M$. anisopliae. Present findings are in corroboration with Khan et al. (2012) [7] who mentioned that members of triazole group including tebuconazole, hexaconazole, propiconazole and difenoconazole were not compatible with $B$. bassiana and $M$. anisopliae and caused complete or strong vegetative growth inhibition and spore germination. Present finding are not in agreement with Reddy et al. (2018) [11] reported that difenoconazole and tricyclazole fungicides were less toxic to Metarhizium anisopliae. The concentration of difenoconazole showed a negative correlation with growth of $M$. anisopliae during 10 days of incubation. A significant negative correlation between the growth of $M$. anisopliae and concentration of tebuconazole had an effect after 10 days of incubation, but it was stronger at 100 and 1000 ppm than difenoconazole, tricyclazole, hexaconazole, propiconazole and myclobutanil. Propiconazole fungicide was less toxic to Metarhizium anisopliae but was highly toxic to Beauveria bassiana and Lecanicillium lecanii @ 1000 and 10,000 ppm treatments implying that triazole fungicides are ineffective against entomopathogenic fungi tested @ 1000 ppm and 10000 ppm. Rachappa et al. (2007) ${ }^{[10]}$ who reported that imidacloprid and spinosad were found safe to the fungus by inhibiting only 11.10 and 5.10 per cent growth, respectively. Dimethoate was found comparatively less detrimental (30.77 to $33.77 \%$ inhibition) to the fungal growth. In general, significantly lesser growth inhibition was noticed in deltamethrin $(36.7 \%)$. Imidacloprid and spinosad can be mixed with the fungus to get enhanced effect. In present finding, dimethoate $30 \%$ EC recorded $69.07 \%$ growth inhibition and imidacloprid $17.8 \%$ SL was found safe to the M. anisopliae. Present findings are not in agreement with Kotwal et al. (2012) ${ }^{[8]}$ who observed that Metarhizium anisopliae and copper oxychloride found to be most compatible and recorded less percent growth inhibition 28.66, 33.00 and 23.00 per cent at three different concentrations.

\section{Conclusion}

Flonicamid 50\% WG was found to be highly compatible with M. anisopliae followed by imidacloprid $17.8 \%$ SL.

\section{References}

1. Abidin AF, Ekowati N, Ratnaningtyas NI. Insecticide compatibility to the entomopathogenic fungi Beauveria bassiana and Metarhizium anisopliae. Scripta Biologica 2017;4(4):273-279.

2. Alves SB. Entomopathogenic fungi. Microbial Control of Insects. Manole, Sao Paulo, Brazil, 1986, 73-126.

3. Asi MR, Bashir MH, Afzal M, Ashfaq M, Sahi ST. Compatibility of entomopathogenic fungi, Metarhizium anisopliae and Paecilomyces fumosoroseus with selective insecticides. Pakistan Journal of Botany 2010;42(6):4207-4214.

4. Bitsadze N, Jaronski S, Khasdan V, Abashidze E, Abashidze M, Latchininsky A et al. Joint action of Beauveria bassiana and the insect growth regulators diflubenzuron and novaluron, on the migratory locust, Locusta migratoria. Journal of Pesticide Science 2013;86:293-300.

5. Filho AB, Jose EM, Almeida, Lamas C. Effect of thiamethoxam on entomopathogenic icroorganisms Neotropical Entomology 2001;30(3):437-447.
6. Joshi M, Gaur N, Pandey R. Compatibility of entomopathogenic fungi Beauveria bassiana and Metarhizium anisopliae with selective pesticides. Journal of Entomology and Zoology Studies 2018;6(4):867-872.

7. Khan S, Bagwan NB, Fatima S, Iqbal MS. In vitro compatibility of two entomopathogenic fungi with selected insecticides, fungicides and plant growth regulators. Libyan Agriculture Research Centre Journal International 2012;3(1):36- 41.

8. Kotwal S, Parate RL, Mane SS, Deshmukh VV. Effect of Metarhizium anisopliae on Spodoptera litura and compatibility with chemicals. International Journal of Science. Environment and Technology 2012;1(5):499505.

9. Niassy S, Maniania NK, Subramanian S, Gitonga ML, Maranga R, Obonyo AB, Ekesi S. Compatibility of Metarhizium anisopliae isolate ICIPE 69 with agrochemicals used in French bean production. International Journal of Pest Management 2012;58(2):131-137.

10. Rachappa V, Lingappa S, Patil RK. Effect of agrochemicals on growth and sporulation of Metarhizium anisopliae (Metschnikoff) Sorokin. Karnataka Journal of Agricultural Sciences 2007;20(2):410-413.

11. Reddy S, Reddy MLN, Pushpalatha M. Interaction of fungicides with bio-control agents. Journal of Entomology and Zoology Studies 2018;6(4):545-551.

12. Sain SK, Monga D, Kumar R, Nagrale DT, Hiremani NS, Kranthi S. Compatibility of entomopathogenic fungi with insecticides and their efficacy for IPM of Bemisia tabaci in cotton. Journal of Pesticide Science 2019;44(2):97105.

13. Silva L, Silva RFP, Heineck MA. In vitro evaluation of the effect of different insecticides on the sporulation of fungus Nomuraea rileyi (Farlow) Samson. Annals of the Entomological Society of Brazil 1993;22:99-103. 